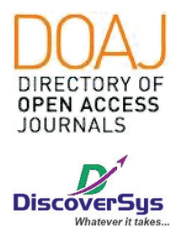

Published by DiscoverSys

\section{Perbedaan rerata kadar protein-C pada sepsis neonatorum dengan kultur positif dan negative di RSUP H. Adam Malik Medan tahun 2018}

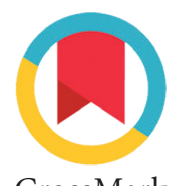

CrossMark

\author{
Jeffry Nugraha, ${ }^{1 *}$ Ricke Loesnihari, ${ }^{1}$ Guslihan Dasa Tjipta²
}

\section{ABSTRACT}

Background: First ten months from conception is a period of susceptibility to infection. Diagnostic testing for disease must be conducted as quickly as possible for antimicrobial administration. Blood culture, the 'gold standard' for diagnosis, is full of shortcomings. Decreasing protein C levels are characteristic of sepsis due to an increase in consumption, degradation, or decreased synthesis, so that the onset of protein C deficiency may occur before the diagnosis of sepsis.

Aim: The study aimed to determine the difference in mean serum C protein levels in septic neonatorum in which positive cultures compared with negative cultures.

Methods: The sample in this study were septic neonatorum patients in the perinatology unit of $\mathrm{H}$. Adam Malik General Hospital Medan by consecutive sampling technique. The blood was incubated in BACTEC 9050 and identified with gram staining, gram-positive identified by catalase, coagulase and MSA tests, while gram-negative with API 20E. Protein C was examined with Coatron A4. A bivariate analysis determined differences in protein $C$ in septic neonatorum with positive and negative cultures.

Result: The prevalence of positive culture sepsis was $36.1 \%$. The most common pathogens were Staphylococci epidermidis (19.4\%). There was no significant difference in protein ( levels between the septic neonatorum with positive and negative cultures $(p=0.166)$. Positive culture sepsis is a risk factor associated with protein C decreasing with $p=0.011$. Positive culture sepsis had a higher risk of reducing protein C levels by 7.536 times compared to negative culture sepsis.

Conclusion: There were no significant differences in protein C levels between septic neonatorum with positive and negative cultures, but sepsis was significantly associated with a decrease in C protein levels.

Keywords: Protein C, septic neonatorum, blood culture

Cite This Article: Nugraha, J., Loesnihari, R., Tjipta, G.D. 2019. Perbedaan rerata kadar protein-C pada sepsis neonatorum dengan kultur positif dan negative di RSUP H. Adam Malik Medan tahun 2018. Intisari Sains Medis 10(2): 380-383. D0I: 10.15562/ism.v10i2.354

\title{
ABSTRAK
}

Latar Belakang: Periode 10 bulan sejak terjadinya konsepsi sampai kelahiran dan 4 minggu pertama kehidupan merupakan masa kerentanan terhadap infeksi.Uji diagnostik untuk infeksi harus dilakukan secepat mungkin untuk pemberian antimikroba. Kultur darah, 'baku emas' untuk diagnosis, penuh dengan kekurangan. Penurunan kadar protein ( adalah karakteristik sepsis karena terjadinya peningkatan konsumsi, degradasi, atau penurunan sintesis, sehingga timbulnya defisiensi protein ( mungkin terjadi sebelum diagnosis sepsis.

Tujuan: untuk mengetahui perbedaan rerata kadar protein C serum pada neonatus sepsis dengan kultur positif dibandingkan dengan kultur negative.

Metode: Sampel pada penelitian ini adalah neonatus sepsis yang dirawat di unit perinatologi RSUP H. Adam Malik Medan. Sampel dipilih dengan teknik consecutive sampling. Darah diinkubasi dengan BACTEC 9050 dan diidentifikasi dengan pewarnaan gram, Bakteri gram positif, diidentifikasi dengan uji katalase, koagulase dan MSA, sedangkan gram negatif dengan API 20E. Protein C diperiksa dengan Coatron A4. Analisis bivariat digunakan untuk mengetahui perbedaan rerata kadar protein C pada neonatus sepsis dengan kultur positif dan negatif.

Hasil: Prevalensi sepsis kultur positif pada penelitian ini adalah 36.1\%. Berdasarkan hasil kultur, patogen yang paling banyak dijumpai adalah Stafilokokus epidermidis (19,4\%). Tidak dijumpai perbedaan yang signifikan pada kadar protein $($ antara kelompok neonatus sepsis dengan kultur positif dan negatif $(P=0.166)$. Dijumpai sepsis kultur positif merupakan faktor risiko yang berhubungan dengan penurunan protein $\mathrm{C}$ dengan $\mathrm{P}=0.011$. Sepsis kultur positif beresiko lebih tinggi mengalami penurunan kadar protein C sebesar 7.536 kali dibandingkan sepsis kultur negatif.

Kesimpulan: Tidak dijumpai perbedaan yang signifikan pada kadar protein C antara kelompok neonatus sepsis dengan kultur positif dan negatif, namun sepsis berhubungan signifikan dengan penurunan kadar protein C. Indonesia,

nugrahajeff@gmail.com

Diterima: $13-11-2018$

Disetujui: 17-04-2019

Diterbitkan: 01-08-2019
Kata Kunci: Protein C, sepsis neonatal, kultur darah

Cite Pasal Ini: Nugraha, J., Loesnihari, R., Tjipta, G.D. 2019. Perbedaan rerata kadar protein-C pada sepsis neonatorum dengan kultur positif dan negative di RSUP H. Adam Malik Medan tahun 2018. Intisari Sains Medis 10(2): 380-383. D0I: 10.15562/ism.v10i2.354 


\section{PENDAHULUAN}

Periode 10 bulan sejak terjadinya konsepsi sampai kelahiran dan 4 minggu pertama kehidupan merupakan masa kerentanan terhadap infeksi. Ketika klinisi menemukan neonatus yang sakit, klinisi harus mencurigai apakah penyakit tersebut merupakan sepsis yang disebabkan oleh bakteri. Diagnosis infeksi neonatal pertama kali dilakukan berdasarkan gejala klinis. Uji diagnostik untuk infeksi harus dilakukan secepat mungkin, diikuti oleh terapi antimikroba empiris sambil menunggu hasil kultur. Pemeriksaan yang utama meliputi kultur cairan serebrospinal dan kultur darah. Dua patogen yang paling sering menyebabkan sepsis neonatal adalah streptokokus grup B dan E. coli. ${ }^{1}$

Sepsis neonatal adalah penyakit sistemik yang disertai dengan bakteriemia yang terjadi pada bulan pertama kehidupan. Kejadian keseluruhan sepsis primer adalah 1-5 per 1000 kelahiran hidup. Insiden ini jauh lebih tinggi untuk bayi dengan berat lahir rendah (berat lahir $<1500 \mathrm{~g}$ ), dengan tingkat sepsis onset awal sebesar $2 \%$ dan tingkat sepsis nosokomial onset lambat sebesar 36\% menurut data dari Pusat Nasional Kesehatan Anak dan Jaringan Penelitian Neonatal Pengembangan Manusia (NICHD-NRN). Angka kematian tinggi (13-25\%); Tingkat yang lebih tinggi terlihat pada bayi prematur dan pada mereka dengan penyakit fulminan dini. ${ }^{2}$

Penggunaan kultur darah, 'baku emas' untuk diagnosis bakteremia, juga penuh dengan kesulitan. Sensitivitasnya juga bergantung pada waktu pengambilan sampel, jumlah sampel, desinfeksi, dan penggunaan antikoagulan. Inkubasi bakteri bisa memakan waktu beberapa hari (2-4 hari). Bakteremia tetap tidak terdeteksi karena volume darah yang diambil sedikit. Ketiga, bakteremia pada neonatus seringkali bersifat sementara atau intermiten, terutama pada tahap awal infeksi. Oleh karena itu, dibutuhkan penelitian untuk mempelajari penanda infeksi yang dapat diandalkan untuk membedakan antara bayi yang terinfeksi dan yang tidak terinfeksi. terakhir. ${ }^{3}$

Jalur protein C, memainkan peran penting dalam respon host terhadap infeksi. Protein $\mathrm{C}$ menginaktivasi faktor-faktor koagulasi, meningkatkan fibrinolisis, dan pada konsentrasi tinggi mengurangi pelepasan sitokin inflamasi. Penurunan kadar protein $\mathrm{C}$ adalah karakteristik sepsis karena terjadinya peningkatan konsumsi, degradasi, atau penurunan sintesis, sehingga timbulnya defisiensi protein $\mathrm{C}$ mungkin terjadi sebelum diagnosis disfungsi organ akibat.infeksi.

\section{METODE}

Penelitian ini merupakan studi analitik potong lintang yang dilakukan pada bulan Februari sampai September 2018 di unit perinatologi RSUP H. Adam Malik Medan. Sampel dipilih dengan teknik consecutive sampling. Sampel merupakan neonatus yang dicurigai sepsis menurut kriteria European Medicines Agency di ruangan perinatologi RSUP H. Adam Malik Medan dalam kurun waktu penelitian, menjalani pemeriksaan kultur darah, dan mendapat persetujuan dari orang tua untuk ikut serta dalam penelitian. Bayi prematur di bawah 34 minggu, neonatus dengan kelainan hati, atau bayi dengan Disseminated Intravascular Coagulation tidak diikutkan dalam penelitian. Penelitian ini dilaksanakan setelah mendapat izin dari Komite Etik Penelitian Kesehatan Fakultas Kedokteran Universitas Sumatera Utara.

Analisis univariat dan bivariat dilakukan terhadap data pada penelitian ini. Untuk data demografis dilakukan analisis univariat sehingga didapatkan distribusi karakteristik sampel. Analisis bivariat digunakan untuk mengetahui perbedaan rerata kadar protein $C$ pada neonatus sepsis dengan kultur positif dan negatif. Uji statistik yang digunakan adalah uji $\mathrm{T}$ independen apabila data berdistribusi normal atau uji Mann Whitney apabila data tidak berdistribusi normal.

Bahan yang digunakan dalam penelitian ini adalah darah dalam vial kultur BACTEC PEDS PLUS/F dan darah dengan antikoagulan Na-citrat 3,2\% (dengan perbandingan 9:1). Darah pada vial kultur BACTEC PEDS PLUS/F untuk dilakukan inkubasi dengan menggunakan BACTEC 9050 dan kemudian diidentifikasi dengan pewarnaan gram. Bakteri gram positif, akan dilanjutkan dengan uji katalase, koagulase dan MSA. Bakteri gram negatif diidentifikasi menggunakan API 20E. Darah dengan antikoagulan sitrat disentrifugasi dengan kecepatan $3500 \mathrm{rpm}$ selama 15 menit dan diperiksa dengan Coatron A4. Setelah pewarnaan Gram diketahui bakteri Gram (+) atau bakteri Gram (-), maka dilanjutkan dengan uji kepekaan antibiotik. Apabila yang tumbuh adalah gram positif, akan dilanjutkan dengan identifikasi bakteri dengan uji katalase, koagulase dan MSA. Apabila yang tumbuh bakteri gram negatif dilanjutkan dengan identifikasi menggunakan API 20E.

\section{HASIL}

Pada penelitian ini diperoleh 36 subjek yang memenuhi kriteria inklusi dan eksklusi. Data dengan skala ukur numerik diuji normalitasnya dengan uji Kolmogorov-Smirnov dan diperoleh hasil bahwa hanya protein $\mathrm{C}$ yang berdistribusi normal. Selanjutnya dilakukan analisis univariat untuk mengetahui distribusi karakteristik sampel dengan hasil seperti yang tertera pada tabel 1 . 
Tabel 1 Distribusi karakteristik subjek penelitian

\begin{tabular}{lc}
\hline Karakteristik & $\mathbf{n = 3 6}$ \\
\hline Median usia, hari (minimum-maksimum) & $1,5(0-30)$ \\
Jenis kelamin, $\mathbf{n}(\%)$ & $18(50,0)$ \\
$\quad$ Laki-laki & $18(50,0)$ \\
$\quad$ Perempuan & \\
Sepsis, $\mathbf{n}(\%)$ & $13(36,1)$ \\
$\quad$ Kultur Positif & $23(63,9)$ \\
$\quad$ Kultur Negatif & $210,1(153,43)$ \\
Rerata kadar protein C (mg/ml) & \\
\hline & $\mathbf{n = 3 6}$ \\
Tabel 2 Tabulasi hasil kultur darah & $7(19.4)$ \\
\hline Patogen & $2(5.6)$ \\
\hline Stafilokokus epidermidis, $\mathrm{n}(\%)$ & $2(5.5)$ \\
Stafilokokus aureus, $\mathrm{n}(\%)$ & $1(2.8)$ \\
Stafilokokus hemolyticus, $\mathrm{n}(\%)$ & $1(2.8)$ \\
Salmonella spp, n (\%) & $23(63.9)$ \\
Klebsiella pneumoniae ssp pneumoniae & \\
Tidak dijumpai, n (\%) & \\
\hline
\end{tabular}

Tabel 3 Perbedaan rerata kadar protein C pada kelompok neonatus sepsis dengan kultur positif dan negatif

\begin{tabular}{llcc}
\hline & \multicolumn{2}{c}{ Sepsis neonatus } & \\
\cline { 2 - 3 } Variabel & Kultur Positif & Kultur Negatif & $\boldsymbol{p}^{*}$ \\
\hline Rerata kadar protein C (mg/ml) & $162.6(176.50)$ & $236.9(135.55)$ & 0.166 \\
\hline
\end{tabular}

${ }^{*}$ uji T independen

Tabel 4 Hubungan faktor risiko dengan skala ukur kategorik dengan penurunan kadar protein $C$

\begin{tabular}{llcc}
\hline & \multicolumn{2}{c}{ Kadar protein C } & \multirow{2}{*}{$\boldsymbol{p}^{*}$} \\
\cline { 2 - 3 } Faktor risiko & Menurun & Normal & 0,171 \\
Jenis kelamin & & & \\
Laki-laki & $9(64,3)$ & $9(40,9)$ & 0,005 \\
$\quad$ Perempuan & $5(35,7)$ & $13(59,1)$ & \\
Sepsis & & & \\
Kultur Positif & $9(64,3)$ & $4(18,2)$ & \\
Kultur Negatif & $5(35,7)$ & $18(81,8)$ & \\
\hline
\end{tabular}

${ }^{*}$ Uji chi square

Tabel 5 Analisis multivariat faktor risiko penurunan kadar protein C

\begin{tabular}{lcccc}
\hline Faktor risiko & Wald & $\boldsymbol{p}^{*}$ & RP & IK95\% \\
\hline Sepsis Kultur Positif & 6.418 & 0.011 & 7.536 & $1.579-35.960$ \\
Jenis kelamin & 1.003 & 0.317 & 2.202 & $0.470-10.326$ \\
\hline
\end{tabular}

${ }^{*}$ Uji regresi logistik

Berdasarkan data tersebut, diketahui prevalensi sepsis kultur positif pada unit perinatologi RSUP
H. Adam Malik pada penelitian ini adalah sebesar $36.1 \%$. Berdasarkan hasil kultur, dijumpai patogen yang paling banyak dijumpai adalah Stafilokokus epidermidis. Data hasil kultur selengkapnya dipaparkan pada tabel 2.

Dilakukan uji T independen untuk mengetahui perbedaan rerata kadar protein C pada kelompok neonatus sepsis dengan kultur positif dan negatif. Berdasarkan uji tersebut, tidak dijumpai perbedaan yang bermakna secara signifikan pada kadar protein $\mathrm{C}$ antara kelompok neonatus sepsis dengan kultur positif dan negatif pada penelitian ini $(\mathrm{P}=0,166)$.

Dilakukan analisis bivariat untuk mengetahui faktor resiko yang berhubungan dengan penurunan kadar protein $\mathrm{C}$ dan akan dianalisis lebih lanjut secara multivariat. Untuk faktor resiko dengan skala ukur kategorik dilakukan uji chi square.

Sepsis kultur positif berhubungan secara signifikan dengan penurunan kadar protein $\mathrm{C}$ $(P=0,005)$ sedangkan jenis kelamin tidak menunjukkan hubungan, namun keduanya akan diikutsertakan dalam analisis multivariat karena memiliki nilai $\mathrm{P}<0,25$. Untuk faktor risiko dengan skala ukur numerik, dilakukan analisis bivariat menggunakan uji $\mathrm{T}$ independent jika data berdistribusi normal dan uji Mann-Whitney jika data tidak berdistribusi normal.

Analisis multivariat dilakukan dengan menggunakan uji regresi logistik. Pada uji regresi logistik, dijumpai faktor risiko yang berhubungan adalah sepsis kultur positif dengan nilai $\mathrm{P}=0.011$. Neonatus dengan sepsis kultur positif memiliki risiko lebih tinggi mengalami penurunan kadar protein $\mathrm{C}$ sebesar 7,536 kali dibandingkan dengan sepsis kultur negatif (IK95\%= 1,579-35,960).

\section{PEMBAHASAN}

Penelitian ini dilakukan sejak bulan Februari sampai Agustus 2018. Pada penelitian ini dikumpulkan 36 sampel pasien dengan diagnosis sepsis yang terdiri dari 18 orang laki laki (50,0\%), 18 orang perempuan $(50,0 \%)$. Hasil penelitian Sianturi et.al laki-laki $(56,8 \%)$ dan perempuan $(43,2 \%){ }^{4}$ Penelitian lain di Jakarta oleh Juniatiningsih et.al juga menunjukkan tidak ada perbedaan statistik yang bermakna antara jenis kelamin dengan sepsis. ${ }^{5}$ Menurut Barizon et al faktor-faktor yang mengatur sintesis dari imunoglobulin terkait dengan kromosom $\mathrm{X}$, sehingga dengan keberagaman kromosom pada perempuan memiliki pertahanan imunologi yang lebih kuat dibanding laki-laki. ${ }^{6}$

Pada penelitian ini didapatkan prevalensi sepsis dengan kultur positif pada unit perinatologi RSUP H. Adam Malik pada penelitian ini adalah sebesar $36,1 \%$. Hasil penelitian Juniatiningsih et al didapatkan terdapat 334 neonatus tersangka sepsis untuk 
pertama kalinya dengan hasil biakan darah positif 148 kasus $(44,3 \%) .5$

Pada penelitian ini, dijumpai patogen yang paling banyak dijumpai adalah Stafilokokus epidermidis. Pada penelitian di RSUP H. Adam malik tahun 2008-2010 bakteri yang paling banyak dijumpai adalah Stafilokokus sp. Pada penelitian lain yang dilakukan oleh Juniatiningsih et al, penyebab sepsis neonatorum tersering adalah Acinobacter calcoaceticus. Sedangkan Stafilokokus epiderdimis merupakan penyebab kedua tersering. ${ }^{5}$

Pada penelitian ini, tidak dijumpai perbedaan yang bermakna secara signifikan pada kadar protein $\mathrm{C}$ antara kelompok neonatus sepsis dengan kultur positif dan negatif ( $p=0,166)$, namun sepsis berhubungan secara signifikan dengan penurunan kadar protein $C(p=0,005)$. Hal ini sesuai dengan penelitian yang dilakukan oleh Beshlawy et.al, protein $\mathrm{C}$ mengalami penurunan secara signifikan $(\mathrm{p}<0,001)^{7}$

\section{SIMPULAN}

Tidak dijumpai perbedaan yang bermakna secara signifikan pada kadar protein C antara kelompok neonatus sepsis dengan kultur positif dan negatif, namun sepsis berhubungan secara signifikan dengan penurunan kadar protein C. Prevalensi sepsis dengan kultur positif pada unit perinatologi RSUP H. Adam Malik pada penelitian ini adalah sebesar $36.1 \%$. Pada penelitian ini, patogen yang paling banyak dijumpai adalah Stafilokokus epidermidis. Penelitian ini memiliki jumlah sampel yang sedikit, dan dilakukan dalam waktu yang singkat, maka perlu penelitian lebih lanjut dengan sampel yang lebih besar dan dalam jangka waktu yang lebih lama, untuk menilai kemampuan protein C dalam mendiagnosis sepsis pada neonatus.

\section{PERSETUJUAN ETIS}

Penelitian ini telah mendapat persetujuan etis sebelum dijalankan oleh komisi etik.

\section{PENDANAAN}

Peneliti bertanggung jawab terhadap pendanaan penelitian secara mandiri.

\section{KONTRIBUSI PENULIS}

Semua penulis memiliki kontribusi yang sama dalam penyusunan artikel hasil penelitian.

\section{DAFTAR PUSTAKA}

1. Ryan K, Ray C, Sherris J. Sherris medical microbiology. 4th ed. New York: McGraw-Hill; 2004: 889.

2. Gomella T, Cunningham M, Eyal F, Tuttle D. Neonatology. 7th ed. New York: McGraw Hill Education Medical. 2013.

3. Ng P, Lam H. Diagnostic markers for neonatal sepsis. Current Opinion in Pediatrics, 2006; 18(2):125-131.

4. Sianturi P, Hasibuan BS, Lubis BM, Azlin E, Tjipta GD. Profil sepsis neonates di Unit Perawatan Neonatus RSUP. H. Adam Malik Medan Tahun 2008-2010. Sari Pediatri. 2017; 14(2):67-72.

5. Juniatiningsih A, Aminullah A, Firmansyah A. Profil Mikroorganisme Penyebab Sepsis Neonatorum di Departemen Ilmu Kesehatan Anak Rumah Sakit Cipto Mangunkusumo Jakarta. Sari Pediatri. 2008; 10(1):60-65.

6. Barizon, A. Karakteristik Sepsis Neonatorum di Unit Perinatology RSUP H. Adam Malik Medan Tahun 20122013. 2015. [online] Repository.usu.ac.id. Available at: http://repository.usu.ac.id/handle/123456789/52411 [Accessed 5 June 2017].

7. El Beshlawy A, Alaraby I, Abou Hussein H, Abou-Elew HH, Mohamed Abdel Kader MS.. Study of protein $\mathrm{C}$, protein $\mathrm{S}$, and antithrombin III in newborns with sepsis. Pediatr Crit Care Med. 2010; 11(1):52-9.

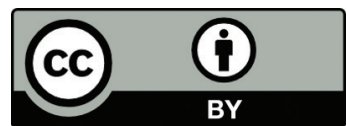

This work is licensed under a Creative Commons Attribution

\section{KONFLIK KEPENTINGAN}

Tidak ada. 